\title{
Evaluation of a Cellular Respiration Instructional Package in the Bachelor of Elementary Education (BEED) Biology Class
}

\author{
Ma. Socorro Gonzaga-Leong-on \\ College of Liberal Arts, Science and Education, University of San Agustin, Iloilo City, 5000, Philippines
}

Received May 12, 2020; Revised October 14, 2020; Accepted October 24, 2020

\section{Cite This Paper in the following Citation Styles}

(a): [1] Ma. Socorro Gonzaga-Leong-on, "Evaluation of a Cellular Respiration Instructional Package in the Bachelor of Elementary Education (BEED) Biology Class," Universal Journal of Educational Research, Vol. 8, No. 12, pp. 6378-6382, 2020. DOI: 10.13189/ujer.2020.081203.

(b): Ma. Socorro Gonzaga-Leong-on (2020). Evaluation of a Cellular Respiration Instructional Package in the Bachelor of Elementary Education (BEED) Biology Class. Universal Journal of Educational Research, 8(12), 6378-6382. DOI: 10.13189/ujer.2020.081203.

Copyright $\bigcirc 2020$ by authors, all rights reserved. Authors agree that this article remains permanently open access under the terms of the Creative Commons Attribution License 4.0 International License

\begin{abstract}
Cellular Respiration, the mechanism of how organisms generate energy to sustain activities while living, is one of the challenging topics to teach and learn in Biology. There is therefore a need for aspiring elementary educators in science to evaluate the defined instructional package for this topic. This study was conducted at a private university in Iloilo City, Philippines, to describe the evaluation of a cellular respiration instructional package in a Bachelor of Elementary Education (BEED) Biology class. This was conducted during the first semester of the school year 2019-2020. The study used descriptive research from 22 out of 23 BEED Biology class. The cellular respiration instructional package significantly increased the BEED Biology class' knowledge $(Z=3.52 ; \mathrm{p}=0.00)$. Generally, the print instructional package for cellular respiration was rated excellent $(\mathrm{M}=91.25 \%, \mathrm{SD}=2.03)$. Creative and rational thoughts, improvement of scientific attitude and reasoning, constructive work, helpfulness or collaboration or cooperation, solidarity and willingness to know the right and the wrong were the top values viewed by the BEED Biology class. The study provided a basis of the use of a developed instructional package for cellular respiration among BEED students.
\end{abstract}

Keywords Biology, Instructional Material/Package, Cellular Respiration, Elementary Education Students

\section{Introduction}

As future science teachers for elementary learners, they need to be able to teach science topics efficiently. The quest for an efficient and successful delivery of teaching to students is therefore a major concern of science educators [1]. To help solve this issue, science educators create instructional packages/materials. These materials can help BEED students to achieve higher order thinking skills of their future students in the 21st century. It has been identified that educational materials, either printed or non-printed, have an impact on the educational process of students [2].

Learners can engage or participate effectively in teaching learning by using instructional materials [3]. Thus, students performed considerably better in various learning activities [4], such as in demanding teaching and understanding subjects.

In Biology, cellular respiration is one of the most difficult subjects to teach and understand [5].To make teaching and learning cellular respiration easier, an established instructional package, module or any learning material will help solve it. During classes, instructional materials and trained science teachers result in meaningful student achievements [2].The impact of these materials is to help achieve the specified behavioral goals when the assessment is carried out at the end of the evaluation [1].

To make cellular respiration topic easy to teach and 
learn, an instructional package was developed. The instructional package adopted the teaching and learning models of the 5Es (engage, explore, illustrate, elaborate and evaluate) constructivists' approach. The instructional package on cellular respiration had introduction containing the engagement part of the 5Es model. It also contained a brief description of the main topic, target audience, expected outcome after using the instructional package and the key questions. The introduction contained also the pretest which measured the initial knowledge of the BEED Biology class students on cellular respiration. Objectives were also included, based on the Biology syllabus. The activity part performed by the students was the exploration part of the 5Es model. It included the objectives, which presented the outcome of the activity. The materials that were needed in the procedure part were also listed. The results part was the area where the BEED students wrote the results of the activity and the questions to be answered. The explanation part of 5Es model discussed the subject matter (cellular respiration) and what had transpired during the activity. The assignment part was the elaboration part of 5Es model. It provided the students the opportunity to learn more and apply what they have learned in the explain part. The post-test part provided the evaluation of the 5Es model. Other parts of the instructional package were the glossary, summary, references and answer key [6].

Although field experts evaluated the cellular respiration instructional package, modifications were made to suit the needs of BEED students. There was a need to implement and assess it among BEED learners in their Biology class. Therefore, this study was carried out to evaluate the cellular respiration instructional package in the BEED Biology class at a private university in Iloilo City, Philippines. In particular, the purpose of the study was to describe the impact of the instructional package on content awareness on the basis of the results of the pre- and post-tests. Another purpose of the study was to also evaluate instructional package in terms of content, structure, presentation and organization, and accuracy and up-to-datedness of the information. The study also aimed at listing the desirable qualities and characteristics of the students. The outcome of the evaluation of the established cellular respiration instructional package provided the basis for using the package to teach cellular respiration in the BEED Biology class.

\section{Methodology}

\subsection{Respondents and Sampling Design}

The developed instructional package for cellular respiration was implemented by holding a Biology class to the 22 out of 23 BEED Biology class students in one private university in Iloilo City, Philippines, during the first semester, school year 2019-20. A purposive sampling design was used in determining the respondents.

\subsection{Study Design and Data Collection Procedure}

The study made use of descriptive research and the nonparametric purposive sampling. A permit from the dean of the college was obtained. The students were made to sign the consent form before the class started. They were made to answer the pretest on cellular respiration. The class started and the instructional package was used. After the class, the students were given a posttest. The assessment rating sheet for written resource materials from the specifications of the Department of Education's Learning Resources Management and Development System (LRMDS) 2009 with modifications was used for the assessment of the instructional package. The basis of the evaluation was the content, design, presentation and organization, and accuracy and up-to-datedness of data. Under the material component of the evaluation, the students were made to consider the desirable attributes and characteristics that can be strengthened by the instructional package.

To assess the difference between the pre-and posttests of the BEED Biology class students, the Wilcoxon Ranked Test was used.

\section{Results}

\subsection{Impact of Cellular Respiration Instructional Package}

The cellular respiration instructional package significantly increased the knowledge of the BEED students $(\mathrm{Z}=3.52 ; \mathrm{p}=0.00)$ (Table 1).

Table 1. Effect of Instructional Package for Cellular Respiration to the Knowledge of the BEED Biology Class

\begin{tabular}{|c|c|c|}
\hline Test & Mean & Standard Deviation \\
\hline Pretest & 3.64 & 1.29 \\
\hline Posttest & 5.09 & 1.15 \\
\hline
\end{tabular}

$Z=3.52 ; p=0.00$ 


\subsection{Evaluation of the Instructional Package}

The result showed that the print instructional package for cellular respiration was generally excellent $(M=91.25 \%$, $S D=2.03$ (Table 2).

Table 2. Evaluation of the Printed Instructional Package for Cellular Respiration

\begin{tabular}{|c|c|c|}
\hline $\begin{array}{c}\text { Areas of } \\
\text { Evaluation }\end{array}$ & $\begin{array}{c}\text { Scores Given by BEED } \\
\text { Students } \\
\text { (mean score and percentage) }\end{array}$ & Description \\
\hline Content (28 pts) & $25.00(89.29 \%)$ & very good \\
\hline Format (72 pts) & $66.67(92.60 \%)$ & excellent \\
\hline $\begin{array}{c}\text { Presentation } \\
\text { Organization } \\
(20 \text { pts) }\end{array}$ & $18.77(93.35 \%)$ & excellent \\
\hline $\begin{array}{c}\text { Accuracy and } \\
\text { up-to-datedness } \\
\text { of information } \\
(24 \text { pts) }\end{array}$ & $21.54(89.75 \%)$ & very good \\
\hline
\end{tabular}

$M=91.25 \quad \%, S D=2.03$

Note: *Passing percentage is $75 \%$. The means were interpreted as follows: $90-100=$ excellent; $85-89=$ very good, $80-84=$ good; $75-79=$ fair; below $75=$ poor

\subsection{Desirable Values and Traits that can be Enhanced by the Instructional Package for Cellular Respiration}

The top values viewed by the BEED Biology class were creative and rational thinking, development of scientific attitude and reasoning, efficient work, helpfulness or collaboration or cooperation, and solidarity and the ability to know what is right and wrong (Table 3). This suggests that these principles have been perceived by many BEED Biology classes as being seen in the instructional package.

Table 3. Product of the Assessment of the Enhancement of the Desirable Values and Characteristics of the Material Portion Instructional Package $(\mathrm{n}=22)$.

\begin{tabular}{|c|c|}
\hline Values & Frequency \\
\hline Pride in Being a Filipino & 4 \\
\hline Scientific Attitude and Reasoning & 15 \\
\hline Desire for Excellence & 9 \\
\hline Love for Country & 7 \\
\hline Helpfulness/Teamwork/Cooperation & 13 \\
\hline Unity & 13 \\
\hline Honesty and Trustworthiness & 9 \\
\hline Ability to Know Right and Wrong & 12 \\
\hline Respect & 16 \\
\hline Critical and Creative Thinking & 15 \\
\hline Productive Work & 8 \\
\hline
\end{tabular}

\section{Discussions}

A major improvement in the subject awareness of the
BEED students was achieved by the instructional package for cellular respiration. This result can be explained by the 5Es constructivists' model used in the instructional package.

A study found out that the constructivist teaching approach of 5Es was more effective in facilitating the interest of students. The model can also fulfill the needs of students and make use of the active use of information and skills [7]. The 5Es model was recommended to be adopted in the school system for teaching biology, like in genetics [8]. It was proposed that the 5Es model should be introduced, as in genetics [8], in the school system for biology teaching. The model has had an important impact on students' achievement and interest, such as Senior Secondary Science Physics students [9]. The 5Es model could catch the interest of science students because the activities are towards investigation. The package significantly increased the knowledge among BEED students on cellular respiration and can also be explained by the presence of lots of information in the material. It could also be due to the understandable procedures that can be done by them. The increased in knowledge can also be due to the familiarity of materials used in the explore part of the instructional package, because the activity was related to their experiences. In one research, writers [8] found that the technical skills, the authentic contributions, the form of material and the boundaries of the content or the limits of the content are authentic. Awareness was discovered as the key factors influencing the design and creation of innovative teaching materials [10].

The students of the BEED Biology class discovered that the content, style, presentation and organization and accuracy complied with the principles of the Management and Learning Resources Management and Development System (LRMDS) 2009 from the Department of Education.

The BEED Biology class students evaluated that the content of the instructional package was suitable to their level of development. It has led to the achievement of the basic goals of the subject area and the level of grade or year for which it is intended. Higher cognitive skills such as logical thinking, imagination, learning by doing, inquiry, and problem solving were developed. Critical thinking has been recognized to be one of the most valuable thinking abilities and one of the most important indicators of the standard of student learning [11]. They also pointed out that ideological, educational, religious, ethnic, and gender biases and stereotypes are free from the manual.

The students of the BEED Biology class gave very good ratings because they pointed out that the content of the cellular respiration instructional package was acceptable to their level of growth. In addition, the kit has helped to meet the specific aims of the subject area and the level of grade/year for which it is intended. The instructional package produced suggested the development of instructional materials to encourage the achievement of the educational objectives (12). 
Higher cognitive skills such as logical thinking, imagination, learning by doing, analysis, and problem solving were also developed in the package. The most important measure of the standard of student learning is critical thinking [12]. The package was free of biases and prejudices that were ideological, cultural, social, ethnic, and gender. The package also encouraged the target readers' curiosity.

According to the BEED students, the format of the instructional package was excellent. The sizes of the letters of the prints were appropriate to the intended user. Spaces between letters and words made reading easier. The font was easy to read. The printing was of good quality (i.e., no broken letters, even density, right alignment, screen registration correctly positioned). The package was simple and has easily recognizable illustrations. The illustrations clarified and supplemented the text and were properly labeled or captioned. The illustrations had realistic/ appropriate colors, attractive, appealing and culturally relevant. It was elegant and fun to look at when it came to design and layout, simple (i.e. not distracting the reader's attention) and had sufficient textual illustration. Design and layout has harmonious blending of elements (e.g., illustrations and text). The instructional kit goes with the recommendation that an instructional material should be presented in various ways to satisfy the various visual needs of students [13]. The paper that was used contributed to easy reading of the package. The package has durable binding to withstand frequent use. The package was easy to handle in terms of size and weight.

An excellent rating on presentation and organization was given by the BEED students on the instructional package for cellular respiration. They saw that the presentations were engaging, interesting, and understandable. There was a logical and seamless flow of ideas. The level of vocabulary was ideal for targeting the experience and comprehension of readers. For the target reader's level of comprehension, the length of the sentences was enough. The BEED Biology class students found out that the instructional package for cellular respiration went with their needs that comprehension scaffolds must address adolescent readers' knowledge and vocabulary needs. For them, the instructional package goes with the need that it must be motivating and engaging readers with the topic and text throughout the reading experience [14].

As to the accuracy and up-to-datedness of information part, the BEED Biology class students gave a rating of very good. They found that the instructional package went with the standard of the LRMDS in terms of conceptual and factual errors, the current information, no over simplified models, examples or simulations. The instructional package reached the LRMDS standard in terms of grammar and spelling. No obsolete information found. No other errors such as errors in illustrations, diagrams, pictures, maps, graphs, and tables in the instructional package for cellular respiration.
These findings were only true on the instructional package for cellular respiration as evaluated by the BEED Biology class in a private university in Iloilo City Philippines.

\section{Conclusions}

This study offers an instructional package for cellular respiration that is effective in increasing the content knowledge among BEED Biology class. The Learning Resources Management and Development System (LRMDS) standard has been passed for areas such as content, format, presentation and organization and quality and up-to-date information components and can improve the development of several desirable values and characteristics. The instructional package for cellular respiration can be used in teaching among BEED students in their Biology class.

\section{Recommendations}

It is recommended for science teachers to use the instructional package in cellular respiration to teach BEED students as supplemental curriculum in Biology subject.

\section{Funding}

This research was funded by the University of San Agustin.

\section{Acknowledgments}

The study was supported by James Pedregosa, PhD, Academic Supervisor-Education and Nenelyn D. Dela Fuente, PhD, Dean, College of Liberal Arts, Sciences, and Education. A gratitude to the second year BEED students, 2019-2020.

\section{REFERENCES}

[1] Awolaju, B. Instructional Materials as Correlates of Students' Academic Performance in Biology in Senior Secondary in Osun State. International, Journal of Information and Education Technology, Vol. 6, No. 9, 2016.

[2] Effiong, L. Oji, E. Igiri, C. Impact of Instructional Materials in Teaching and Learning of Biology in Senior Secondary Schools in Yakurr, International Letters of Social and Humanistic Sciences, Vol. 62, 27-33, 2015.

[3] Adebule, S. Ayoola, O. Impact of Instructional Materials on Students' Academic Performance in Mathematics in Secondary Schools in Ekiti State, Nigeria, Research Journal 
of Educational Studies and Review, Vol. 2, No. 1, 1-4, 2016.

[4] Achola, O. Gudo, C. Odongo, B. Implications of Instructional Materials on Oral skills among Early Childhood Learners in Central Zone, Kisumu County, Kenya, International Journal of Educational Policy Research and Review, Vol. 3, No. 2, 20-28, 2016.

[5] Tekkaya, C. Özlem, Ö. Semra, S. Biology Concepts Perceived as Difficult by Turkish High School Students, Hacettepe Üniversitesi Eğitim Fakültesi Dergisi, Vol. 21, 145-150, 2001.

[6] Leong-on, M.S. Espina, B. Development and Evaluation of an Instructional Package for the Topic Cellular Respiration in Biology for Grade12 Science, Technology, Engineering and Mathematics (STEM) Track, International Journal of Science and Research (IJSR). Vol. 9, No. 2, 270-274, 2020.

[7] Bybee, R. Achieving scientific literacy: From purposes to practices, Heinemann Publications, United States of America, 1997.

[8] Agogo, P.O. Naakaa, D.A. Effects of 5Es Constructivism Instructional Strategy on Students' Interest in Senior Secondary Genetics in Gwer Local Government Area, Benue State, Nigeria, Global Journal of Environmental Science and Technology, Vol. 1, No. 2, 15-19, 2014.
[9] Akanwa, U. N. Ovute, A.O. The Effect of Constructivist Teaching Model on SSS Physics Students' Achievement and Interest, IOSR Journal of Research \&Method in Education, 4(1), 35-38, 2014.

[10] Sendurur, E., Cetin, I., Ersoy, E. The Design and Development of Creative Instructional Materials: The Role of Domain Familiarity for Creative Solutions. International Journal of Technology and Design Education, Vol. 28, 507-522, 2018.

[11] Alsaleh, N. Teaching Critical Thinking Skills: Literature Review, Turkish Online Journal of Educational Technology, Vol 19, No. 1, 21-39, 2020.

[12] Manurung, K. Designing Instructional Material, Palu: Untad Press, Indonesia, 2017.

[13] Tomita, K. Visual Design as a Holistic Experience: How Students Engage with Instructional Materials of Various Visual Designs, Indiana University ProQuest Dissertations Publishing, United States of America, 2017.

[14] Lupo, S. Conradi Smith, K. Strong, J. "Struggle" Is Not a Bad Word: Misconceptions and Recommendations about Readers Struggling with Difficult Texts. Journal of Adolescent \& Adult Literacy, 62(5), 551-560, 2019. 